\title{
Forest Dependence among Rural Households in Southern Ghana: Implications for Conservation and Poverty Reduction
}

\author{
Philip Prince Kwasi Mantey ${ }^{1}$ \\ Joseph Kofi Teye ${ }^{2}$
}

\begin{abstract}
While it is widely acknowledged that an understanding of the determinants of rural households' forest extraction and dependence on forest resources is important for policies on forest conservation and rural development, the factors that determine Ghanaian households' dependence on forests are neither adequately explored nor well-understood. Against this background, this paper examines the extraction and dependence on forest resources among rural households in the forest communities of Southern Ghana. Data were collected through a household livelihood survey and in-depth interviews in two forest communities. Regression models were then used to investigate key factors that condition the households' dependence on forests in the study communities. The findings indicate that almost all households are engaged in forest extraction. The average overall contribution of forests to household income in the study communities was 21 percent and constituted the third largest contributor to household income following crop income and non-farm income. The findings also indicate that forests also play an essential safety net role in the face of unforeseen income shortfalls and ultimately, in poverty alleviation. The results further reveal that the rural household's extraction of forest resources and consequently its dependence on forests (livelihood strategy) are a function of its access to other livelihood assets, its vulnerability context as well as other context variables. Recommended policy interventions for forest conservation and sustainable rural development include securing the natural resource base, broadening poor people's livelihood options and improving access to education in rural communities.
\end{abstract}

Keywords: Forest resources, Forest dependence, Rural Livelihoods, Regression

\footnotetext{
${ }^{1}$ University of Ghana, School of Continuing and Distance Education

${ }^{2}$ University of Ghana, Department of Geography \& Resource Development. *Corresponding author email: jkteye@ug.edu.gh
}

Ghana Journal of Geography Vol. 13 (1), 2021 pages 1-24

https://dx.doi.org/10.4314/gjg.v13i1.1 


\section{Introduction}

Forests have been central in human history; providing a wide range of goods and services. In the last two decades, the ecosystem functions of forests have gained increasing attention in both the academic and policy circles (FAO, 2015; O'Gorman, 2006; Tittensor et al., 2014). There is increasing understanding among development practitioners that many rural livelihoods and cultures in less developed countries are fundamentally linked to environmental resources, particularly forests (Acheampong \& Marfo, 2011; Asamoah et al., 2007). Non-timber forest products (NTFPs), for example, play a major role in providing livelihoods and food security, especially for the rural poor (Acheampong \& Marfo, 2011; Dash \& Behera, 2016; Domson \& Vlosky, 2007; Falconer, 1992; Wunder et al., 2014). Studies from tropical forest areas document the many important roles of forests in rural livelihoods, providing a plethora of subsistence goods, marketable products for cash income generation, production inputs to agriculture, and vital safety nets in difficult times (Byron \& Arnold, 1999; Chilongo, 2014; Córdova et al., 2013; Godoy et al., 2002; Vedeld et al., 2007). There is a wide range of livelihood strategies pursued by households in forest communities; while some households rely on one or few activities, others households diversify their livelihood strategies (Appiah et al., 2009; Asamoah et al., 2007). In some cases, the extraction and sale of NTFPs is the major and even sometimes the only source of income for some vulnerable rural households (Asamoah et al., 2007).

Some scholars have, however, contended that although access to forest income helps the poor to survive, it may not help them move out of poverty (Neumann \& Hirsch, 2000; Wunder, 2005). The view that rural households are dependent on forest resources is nonetheless commonly acknowledged by development researchers (Cavendish, 2000; Fisher, 2004; Gatiso \& Wossen, 2015; Vedeld et al., 2004; Wunder et al., 2014). The continued availability and access to NTFPs in the forest communities is, however, being threatened by the swelling demand for farmland in developing countries in tandem with their growing populations. This, according to Illukpitiya and Yanagida (2010), has raised the opportunity costs of environmental preservation. Sustainable use and conservation of forest resources has thus become necessary for future prosperity and development. It has been increasingly recognised by researchers that understanding the underlying relationships between people and their local environmental resources is vital to the design and sustainability of any effective conservation strategies (Coomes et al., 2004; Mamo et al., 2007). This is particularly in the areas where conflicts may 
limit the acceptance of desired conservation outcomes (Balint, 2006; Lilieholm \& Romney, 2000; Whitesell et al., 2002).

In the last two decades, interest has been on the contributions of forests to household income, welfare and local employment in rural communities (Arnold \& Townson, 1998; Byron \& Arnold, 1999; McSweeney, 2004) spanning multiple perspectives, such as political ecology and resource management. However, investigations on the rural households' dependence on forests are now emerging for developing countries (Adhikari et al., 2004; Brobbey et al., 2019; Cavendish, 2000, 2002; Chilongo, 2014; Dash \& Behera, 2016; Fisher, 2004; Mamo et al., 2007; Vedeld et al., 2004). In Ghana, for instance, the very few studies on communities' use of forest resources (Amanor, 1999; Appiah et al., 2009; Brobbey et al., 2019; Falconer, 1992; Wiggins et al., 2004) tend to focus on the contribution of forests to the livelihood strategies. The determinants of Ghanaian rural households' dependence on forests have not been adequately analyzed, although it is widely acknowledged that an understanding of the determinants of households' forest extraction and dependence on forest resources is important for policies on forest conservation and rural development. Another neglected research gap that requires attention is how information on distinct patterns of forest resource use and dependence could be used to target conservation-development initiatives and poverty reduction. The acknowledged variation in the manner and degree to which people within even the same community engage in forest extraction activities also calls for a closer look into forest dependence across different socioeconomic groups. This paper, therefore, examines the determinants of the rural households' level of economic dependence on forests as well as their implications for sustainable forest management and poverty reduction in Ghana.

The rest of the paper is structured as follows: the next section presents the conceptual framework for the study, which is followed by the materials and methods. After that, the results and discussions are presented and finally, ends with the conclusion.

\section{Conceptual Framework}

The study draws on insights from the sustainable rural livelihood framework (DFID, 1999), which enables us to have a wider conceptualisation of the rural household's livelihood activities and the factors conditioning them. Chambers and Conway (1992, pp. 7-8), assert that "A livelihood comprises the capabilities, assets and activities required for a means of living: a livelihood is sustainable, which can cope with and recover from stress and shocks, maintain or enhance its capabilities and assets, and provide sustainable livelihood opportunities for the next 
generation; and which contributes net benefits to other livelihoods at the local and global levels and in the long and short term."

The livelihood framework focuses on households' access to five types of 'capital' or 'assets' summarized by (Scoones, 1998) as: natural (environmental) capital (land, water, wildlife, biodiversity, environmental resources); physical capital (water, sanitation, energy, transport, communications), housing and the means and equipment of production; human capital (health, knowledge, skills, information, ability to labour; social capital (relationships of trust, membership of groups, networks, access to wider institutions); and financial capital (wages, regular remittances or pensions, savings, supplies of credit). Following this proposition, a households livelihood strategy and the outcome thereof is a function of the assets at its disposal (Barham et al., 1999; Barrett et al., 2005; Brown et al., 2006; Dercon, 1998). The framework views households operating in a context of vulnerability, which influences the way and manner in which they allocate their asset endowments to different livelihood strategies -the ways in which people combine and use assets in pursuit of beneficial livelihood outcomes that meet their own livelihood objectives. Livelihoods are additionally shaped by policies, institutions and processes (PIPs) that operate from the household to the international level. These also influence access to the various types of capital (natural, physical, human, social and financial) and consequently livelihood strategies. The implementation of policies, legislation and regulations by various public institutions and the processes by which they operate and interact have an impact on the conditions that promote the achievement of livelihood strategies and sustainable livelihoods. In the context of this study, the rural poor are affected by the PIPs that regulate the natural environment.

Brown et al. (2006) observe that a farm household generates income by allocating its asset endowments across different economic activities with a view to maximising returns. The inability to choose a superior strategy can therefore, be attributed to household asset endowment constraints when income derived from the different activities are ordered in welfare terms. The implication of this is that some households are compelled to select less rewarding strategies because they are constrained in choosing strategies offering superior returns since no one would freely choose a less rewarding strategy in the face of better alternatives. The viability and effectiveness of livelihood strategies is, therefore, dependent upon the particular configuration of a household's asset as well as the vulnerability and institutional contexts that regulates access to them. Forest extraction as a livelihood strategy is, therefore, a choice pursued by rural households given their particular asset configuration, the 
vulnerability context and policies and institutions in operation. This gives rise to a range of resource use outcomes that are as varied as the distinct combination of household assets.

Figure 1 schematically presents the various components of the adapted livelihood framework (DFID, 1999) illustrating the dependence of household livelihood strategy on 'assets', the vulnerability and policy and institutional contexts.

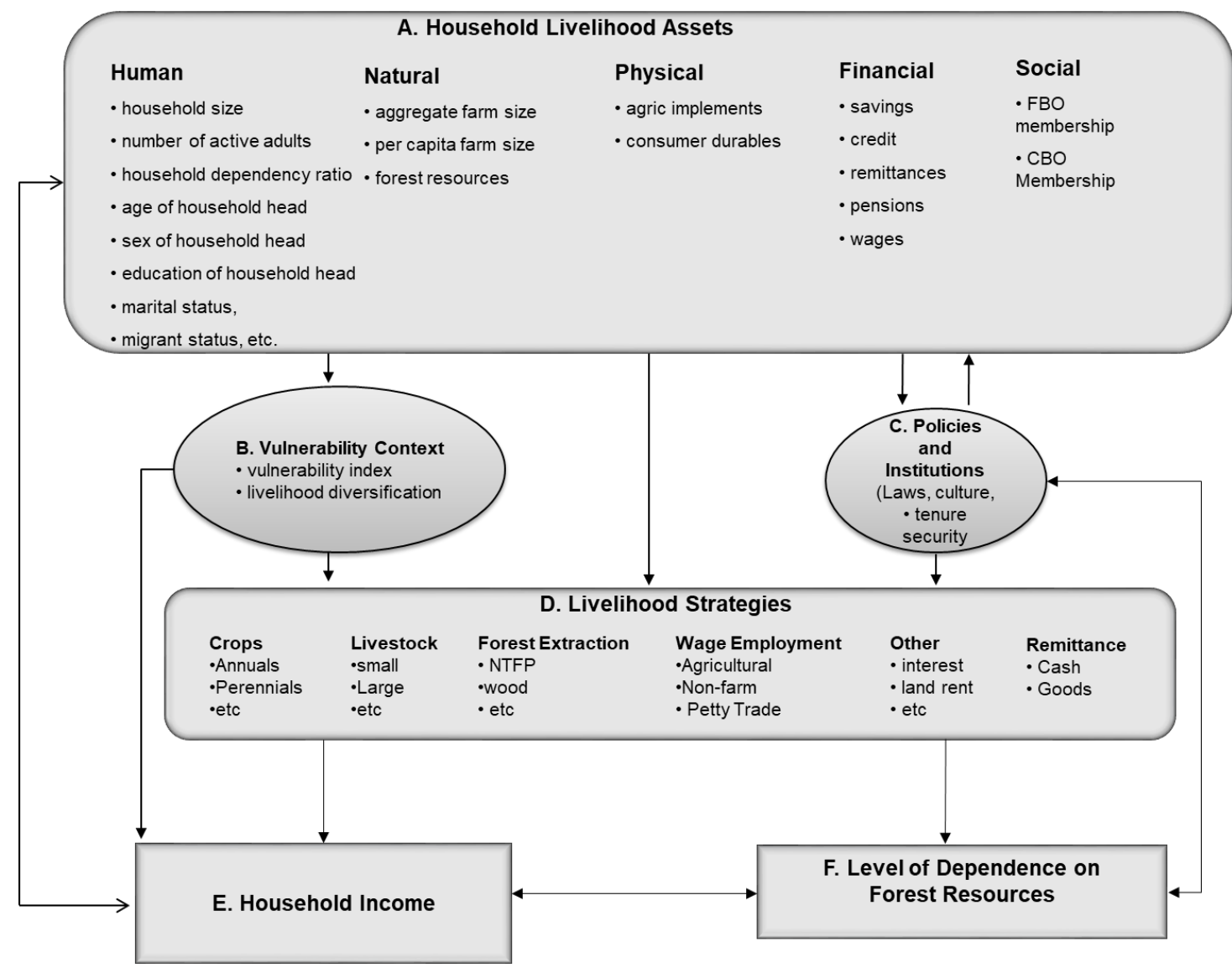

Figure 1: Conceptual Framework (Adapted from the Sustainable Livelihoods Approach; DFID 1999)

At the heart of the framework is the household's livelihood strategy or set of strategies (D) the pursuit of which is a function of its asset endowment: human, natural, physical, financial and social resources (A). Besides, its asset configuration, a household's livelihood strategy (D) may also be influenced by exogenous factors such as the vulnerability context (B) as well as the policies and institutions (C). A given household's livelihood strategy generates livelihood outcomes such as food, cash income and sustainable natural resource management, denominated in this study in terms of household income (E). The household's asset endowments themselves are revised endogenously by outcome effects (i.e., investment in household assets, fertility shifts, and migration from/to household) and through resource use (i.e., stock depletion). A combination of the household's asset endowments and livelihood 
strategies mediated by idiosyncratic shocks and local institutions ultimately determines the income generated by the household and consequently the importance of, and level of dependence of the household, on a given livelihood strategy. A livelihood strategy, which includes forest resource extraction as a component can give insights to the relative importance of the different categories of forest resources to the household as well as the household's level of economic dependence on forests (F). In this study, the household's level of dependence on forest is captured as the share of household total income from forests (relative forest income). Many conceptual and empirical studies on income diversification and livelihood strategies have adopted a similar framework (Babulo et al., 2009; Bebbington, 1999; Coomes et al., 2004; Dercon, 1998; Ellis \& Freeman, 2004; Jansen et al., 2006; Reardon \& Vosti, 1995).

\section{Materials and Methods}

\section{Study Communities}

The paper was based on a study conducted in two forest communities namely, Ahumahumaso in the Eastern Region and Odumase in the Central Region (fig. 2) of Ghana. Ahumahumaso is located on longitude $0^{\circ} 22^{\prime}$ West and latitude $6^{\circ} 30^{\prime}$ North and is very close to the Wurobong South Forest Reserve. Although quite remote like many forest communities, it is generally accessible and lies about 17 kilometres from the nearest large town. Ahumahumaso has a sizeable migrant population. Freeholders who are mainly indigenes dominate tenure arrangements. Leaseholders and the popular share cropping arrangements are usually the preserve of migrant households. 


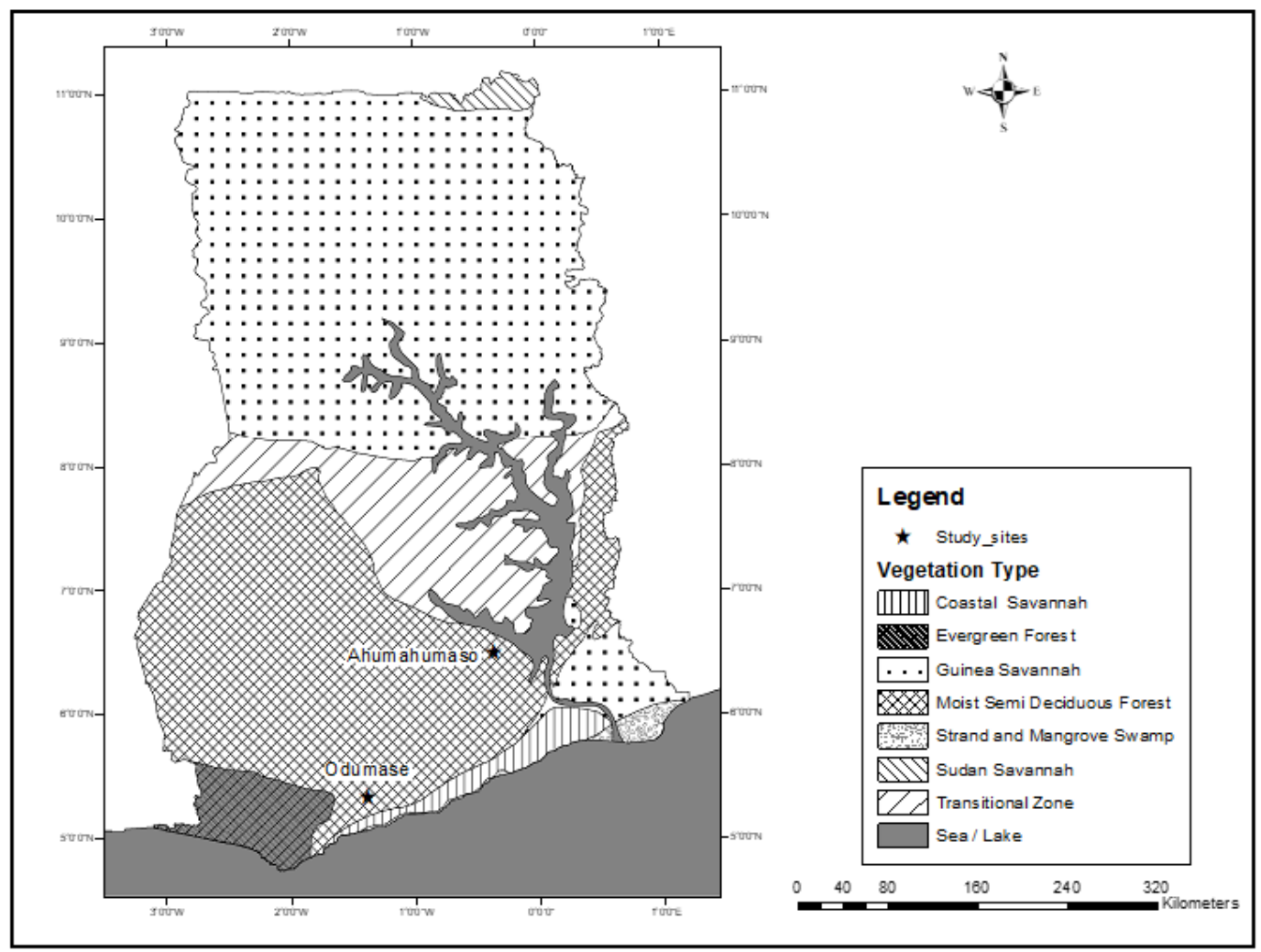

Figure 2: Ecological map of Ghana showing the study communities. (Author's elaboration).

The forest resources available to this community are plentiful given that it is surrounded by substantial forest vegetation and is within the buffer zone of the Wurobong South Forest Reserve, which is mostly degraded due to over exploitation and the extension of human activities into the enclave. Agro forestry practices adopted in the past, which allowed farming in the reserve in exchange for tree planting by the farmers for the regeneration of the forest has failed to achieve the desired results because of conflict in perspectives between the farmers and conservationists.

The second study site, Odumase is also a farming community in the Central Region of Ghana and is located on longitude $1^{\circ} 22^{\prime}$ 'West and latitude $5^{\circ} 19^{\prime}$ North. The Kakum National Park, which lies to the east of this community covers an area of 209 square kilometers and is part of the remaining tropical rainforest ecosystem in Ghana. The Pra Suhyen Forest Reserve also lies to the West of the community. The general features of this community are similar to those of the first study site but with some notable differences. The community is serviced by a tarmac road and is about $25 \mathrm{~km}$ from the nearest large town. The ethnic composition of households in Odumase is largely homogenous with very few non-indigenes. Households here do not have access to the surrounding forest reserves for farming unlike in Ahumahumaso because of the 
strict protectionist policies regarding the management of the reserves. The households however freely exploit the off-reserve community forest resources, which are quite substantial. The production of annual cash crops such as oil palm and cocoa is the dominant farming activity besides the regular staples of maize, cassava and plantain. The major household enterprises include petty trading, food enterprises palm oil and palm kernel oil production.

\section{Methods of data collection}

Primary data for the study was largely collected through a household survey in the study communities in a two-stage sampling design. Firstly, two out of the four main regions of Ghana within the forest ecological zone of the country were randomly selected for the study namely, the Eastern and Central Regions. The final sampling unit is a community (natural village) which lies in the buffer zone of a forest reserve in the selected region. From the list of such communities for each of the selected regions, two were randomly selected for the study, namely Ahumahumaso and Odumase in the Eastern and Central Regions respectively. Once this was achieved, a representative random sample of 160 households from Ahumahumaso and 100 households from Odumase were selected for the survey yielding a total sample size of 260 households.

The quantitative data was collected using questionnaire, primarily designed to capture information on household characteristics, livelihood assets and income sources. Detailed questions on all relevant inputs and outputs were included to allow for the calculation of net incomes (sale and consumption) for all sub-categories of income with 2014 as the year in reference. Recall periods in the survey followed the annual production cycle at a maximum of twelve months. It would, however, be prudent to treat figures on forest incomes as conservative estimates since recall accuracy and biases cannot be totally eliminated.

The quantitative data was analysed using the SPSS / STATA statistical software and involved the use of descriptive statistics to analyse trends and econometric modelling and regression analysis were then used to decipher associations and relationship between household variables, people's livelihoods and forests. The total net income (cash and kind) approach described by Cavendish (2002), as a broad measure of a household's economic welfare status was used. Household total income was consequently distinguished into six major categories: forest income, crop income, livestock income, non-farm income, remittances and miscellaneous income.

The quantitative data from the survey was supplemented with data collected through interviews with 9 key informants (comprising traditional authorities, forest guards, assembly members) and 22 household 
heads selected from the two study communities. These interviewees earlier completed the questionnaire and were selected for further interviews. These further interviews were meant to clarify and explain some of the quantitative findings, in line with sequential explanatory mixed methods strategy. This current paper, however, largely focused on the quantitative data.

\section{Definitions and Measurement of key variables}

\section{Dependence on Forest Resources}

The household's level of dependence on forest resources was captured using the relative forest income (RFI), which is the percentage of the total household income derived from the exploitation and consumption of forest resources. Household income from the different livelihood activities were estimated based on reported production figures for the year at prevailing market prices. Physical assets were also subjectively valuated by respondents based on current resale value (see (Takasaki et al., 2000). The household's forest dependency level was then obtained by accounting for its relative forest income (see Mamo et al., 2007; Vedeld et al., 2004; Vedeld et al., 2007). The relative forest income (RFI) is a simple but important measure of reliance, or dependence, on forest environmental income and is given by:

$R F I=A F I / A I$

Where RFI is relative forest income, AI is absolute total income and AFI is Absolute forest income (consumption and cash form, from all forest income sources and products).

\section{Factors Affecting a Household's Level of Dependence on Forests}

Robust regression of households' relative forest income (sale and consumption) on household asset-based variables, household characteristics and other context variables was ran to determine correlates of forest dependence strategies. Robust regression models are stable and reliable, despite the presence of influential outliers and the non-normality as well as heteroscedasticity of residuals. Livelihood diversification was captured using Simpson's index of diversity as captured in (Illukpitiya \& Yanagida, 2010) and is given as: 
Diversityindex $=1 / \sum_{i}^{N} P_{i}^{2}$

Where:

$P_{i}=$ proportion of total income contributed by income source $i$

$N=$ number of income sources

The regression model is given as:

$$
Y_{i}=\beta_{0}+\beta_{1} X_{i}+\varepsilon_{i}
$$

Where $Y_{1}$ is the dependent variable (household's relative forest income), $X_{i}$ is a vector of household characteristics (household capital assets, context variables, control variables) $\quad, \quad \beta_{0}$ is $\quad$ Constant term, $\beta_{1}$ is a vector of regression coefficients which we wish to estimate and $\varepsilon_{i}$ is the error term.

\section{Results and Discussions}

\section{Household Income Shares and Sources}

As a way of analyzing the contribution of forest to income, we present Table 1, which shows the distribution of total household income by source or livelihood activities within 12 months prior to the study. In Ahumahumaso, crop income share is the highest, accounting for 41 percent of total household income, followed by non-farm income (30 percent) and forest income (22 percent). The remainder is made up of remittances (5 percent) and Livestock (2 percent). In Odumase, non-farm income share is the highest, representing 36 percent, followed by crop income (33 percent) and forest income (19 percent). Remittances ( 8 percent), livestock (3 percent) and Miscellaneous (2 percent) make up the rest of the income shares.

The high proportion of income from the forests is explained by the fact that the study communities depend on forests for a wide range of resources, such as domestic energy needs, construction materials, fences, farm implements and wooden furniture. Firewood, wild fruits (mango, orange, pear, etc.) and bush meat are the major sources of forest income in the study communities. Regular trapping of wild birds, rats, grass cutter and the occasional ruminant, serves as major sources of protein for most rural households but are also sold to raise cash for other essential household purchases. The average overall contribution of forest resources to household income for the total sample was 21 percent. The fact that the forest income shares remains uniformly high across the study sites reflects opportunities and relatively high returns 
to some forest extraction activities arising from local resource endowments, access regimes and markets as well as the firm connection between the peoples' livelihoods to agriculture and natural resource use.

Table 1: Household Income Shares by Source and Community

\begin{tabular}{lllllll}
\hline Income source & \multicolumn{2}{l}{ Ahumahumaso } & Odumase & & Total & \\
\hline & Mean & SD & Mean & SD & Mean & SD \\
\hline Forests & 0.22 & 0.2 & 0.19 & 0.15 & 0.21 & 0.19 \\
\hline Crops & 0.41 & 0.32 & 0.33 & 0.27 & 0.38 & 0.31 \\
\hline Remittances & 0.05 & 0.16 & 0.08 & 0.16 & 0.06 & 0.16 \\
\hline Non-farm & 0.3 & 0.36 & 0.36 & 0.37 & 0.32 & 0.37 \\
\hline Livestock & 0.02 & 0.04 & 0.03 & 0.05 & 0.02 & 0.04 \\
\hline Miscellaneous & - & 0.01 & 0.02 & 0.11 & 0.01 & 0.07 \\
\hline $\mathrm{N}$ & 160 & & 100 & & 260 & \\
\hline
\end{tabular}

Source: Field work, 2014

In both study sites, access to community forests is unrestricted. In the case of reserves, households in Ahumahumaso appear to have unfettered access to the neighbouring Wurobong South Reserve and may account for the slightly higher forest income shares recorded there compared to households in Odumase where there is strict restriction of access to the Kakum Reserve, as highlighted in the statement below by a farmer at Odumase:

The [Kakum] forest reserve has useful resources, like animals that one can hunt but the government does not allow us to go there to kill animals or cut down trees. The forest guards are very strict with these rules so we don't go there to harvest resources. (Dumeta, farmer, Odumasi).

On the other hand, the larger share of non-farm income in Odumase reflects the preponderance of petty trading and agro-processing activities notably oil palm production relative to Ahumahumaso, a predominantly farming community. The results suggest that diversified household livelihood strategies and income sources was common in the study communities and is not merely a feature of aggregation across specialist households. This is to be expected in rural areas with underdeveloped markets for credit and insurance. Asset, income and livelihood diversification in such circumstances emerge as important for risk mitigation (ex-ante). Diversification also helps with coping with the unexpected shortfalls in household income from given sources -income shocks (Barrett et al., 2001). In sum, the data showed that forest income was very important for households in the study villages, accounting for about 21 percent of total household income on average and constituting the third largest contributor following crop 
income (38\%) and non-farm income (32\%). The finding is not strikingly peculiar as high income shares from environmental resources have also been reported to account for about 35 percent of household income in Zimbabwe (Cavendish, 1999), 30 percent in Malawi (Fisher, 2004) and 39 percent in the Dendi District of Ethiopia (Mamo et al, 2007). The contribution of forest environmental income to total household income in the study sites highlights the fact that forest resources are not only important in their gap-filling role, but also in the absolute magnitude of their contribution to the household's livelihood portfolio.

Household income shares were also disaggregated by source and income quartiles to analyse whether poorer households in rural communities were more dependent on forests for their livelihoods. Table 2 reports average income shares by livelihood source and income quartiles for sample households in the study communities in Ghanaian Cedi. The data showed that the first and second income quartiles reported the highest forest income shares of 27 percent and 23 percent respectively. Forest income shares for the third and fourth income quartiles showed a reduced reliance on forest resources with shares of 19 percent and 14 percent respectively. In fact, for the two lowest income quartiles, forest income shares are second only to that of crop income. For the third and fourth income quartiles, forest income shares come third in importance to non-farm and crop income.

Table 2: Household income shares by source and income quartiles*

\begin{tabular}{|c|c|c|c|c|}
\hline & & Inco & tiles & \\
\hline & $1 \mathrm{st}$ & 2nd & $3 \mathrm{rd}$ & 4th \\
\hline Total household Income & 3411.03 & 4887.47 & 6298.45 & 9308.35 \\
\hline Per Capita Income & 629.06 & 1139.56 & 1896.81 & 4741.89 \\
\hline Forest income & $\begin{array}{c}904.75 \\
(0.27)\end{array}$ & $\begin{array}{c}1087.57 \\
(0.23)\end{array}$ & $\begin{array}{c}934.40 \\
(0.19)\end{array}$ & $\begin{array}{c}948.91 \\
(0.14)\end{array}$ \\
\hline Crop income & $\begin{array}{c}1453.23 \\
(0.43)\end{array}$ & $\begin{array}{c}2507.52 \\
(0.46)\end{array}$ & $\begin{array}{c}1926.61 \\
(0.33)\end{array}$ & $\begin{array}{c}2226.77 \\
(0.29)\end{array}$ \\
\hline Remittances & $\begin{array}{l}174.93 \\
(0.06)\end{array}$ & $\begin{array}{l}118.40 \\
(0.06)\end{array}$ & $\begin{array}{l}277.55 \\
(0.09)\end{array}$ & $\begin{array}{l}277.97 \\
(0.04)\end{array}$ \\
\hline Non-farm income & $\begin{array}{c}782.29 \\
(0.21)\end{array}$ & $\begin{array}{c}989.87 \\
(0.22)\end{array}$ & $\begin{array}{c}338.62 \\
(0.34)\end{array}$ & $\begin{array}{c}5689.60 \\
(0.51)\end{array}$ \\
\hline Livestock income & $\begin{array}{l}95.15 \\
(0.03)\end{array}$ & $\begin{array}{l}139.09 \\
(0.03)\end{array}$ & $\begin{array}{l}156.80 \\
(0.02)\end{array}$ & $\begin{array}{c}156.80 \\
(0.02)\end{array}$ \\
\hline Miscellaneous income & $\begin{array}{c}0.64 \\
(0)\end{array}$ & $\begin{array}{l}44.80 \\
(0.01)\end{array}$ & $\begin{array}{l}45.01 \\
(0.03)\end{array}$ & $\begin{array}{c}8.32 \\
(0)\end{array}$ \\
\hline $\mathrm{N}$ & 65 & 65 & 65 & 65 \\
\hline
\end{tabular}

Source: Field work, 2014, *1 USD to 3.2 Cedis, Proportions in brackets 
The findings indicate that lower income households derived a larger share of their income from forest resources relative to households with higher income levels. This is clearly captured in the statement below by a poor female household head:

As you can see life is not easy at all for me and my three children. Our farms are always small because we do not have big land and we sometimes work on other people's farms so that they give us food stuff. I have realized that people always cheat us when we work for them. So these days we always go to the forest to cut firewood and look for snails, which I sell for money. All our income come from the forest resources I harvest and sell.... Some of the parents here have their educated children working in towns and sending money to them so they do not suffer. However, I am not lucky as my children could not go to high school so they are all here with me..." (Anota, female household head, Ahumahumaso)

From the above quotation, one can state that poorer households derive a higher proportion of income from forests because given their limited access to land and low levels of human capital, they find forest extraction as a viable livelihood source. These characteristics often mean that forest extraction is ideally suited for low income or resource poor households who find it relatively easy to engage in it whereas the better off have less interest in doing so.

\section{Dependence on Forests}

As already indicated Table 1, site-specific forest dependency figures show an average dependency level of 22 percent for Ahumahumaso and 19 percent in Odumase. The observed differences in forest dependency levels in the two sites, albeit marginal, are likely a function of differing opportunities arising from resource endowments, market access and forest management regimes at the sites. A disaggregation of household income shares by source and level of forest dependence is presented in Table 3. The level of forest dependence was sub categorized into terciles represented by the less dependent $(0-33$ percent), dependent (33 - 66 percent) and very dependent (above 66 percent) households. The average income shares from forests for the less dependent category accounted for just 2 percent of household income while non-farm income and crop income accounted for 57 percent and 30 percent respectively. For the dependent category, average forest income shares accounted for 17 percent of household income whereas crop and non-farm shares accounted for 45 percent and 29 percent respectively. The very dependent category on the other hand reported a high average forest dependency level of 43 percent followed by crop income with 38 percent and non-farm income with 10 percent. Thus, forest extraction activities amongst households in the very dependent category are the most important in its livelihood portfolio. 
Table 2: Household income shares by source and forest dependency level

\begin{tabular}{lllllll}
\hline \multirow{2}{*}{ Income Source } & \multicolumn{2}{l}{ Less Dependent } & \multicolumn{2}{l}{ Dependent } & \multicolumn{2}{l}{ Very Dependent } \\
\cline { 2 - 7 } & Mean & Std. error & Mean & Std. error & Mean & Std. error \\
\hline Forests & 0.02 & 0 & 0.17 & 0.01 & 0.43 & 0.01 \\
\hline Crop & 0.3 & 0.04 & 0.45 & 0.03 & 0.38 & 0.02 \\
\hline Remittances & 0.08 & 0.02 & 0.05 & 0.01 & 0.06 & 0.01 \\
\hline Non-farm & 0.57 & 0.04 & 0.29 & 0.03 & 0.1 & 0.02 \\
\hline Livestock & 0.01 & 0 & 0.03 & 0.01 & 0.02 & 0 \\
\hline Miscellaneous & 0.02 & 0.01 & 0.01 & 0 & 0 & 0 \\
\hline $\mathrm{N}$ & $86(0.33)$ & $89(0.34)$ & $85(0.33)$ \\
\hline
\end{tabular}

Source: Field work, 2014

From an economic perspective, several reasons account for household level variation in the adaptation and utilization of available forest resources based on their peculiar socio-economic characteristics. While some of these factors relate to the household characteristics, others are contextual. Some of the household level factors may have to do with the human resource and other asset endowments, consumption motives, and their response to unforeseen income shortfalls. Table 4 presents some household characteristics and contextual factors stratified by levels of forest dependence. Key differences between the less dependent and highly dependent groups show smaller household sizes and lower dependency ratio for the less dependent group. Also highlighted here is the greater level of forest income derived by the very dependent group compared with the dependent and less dependent ones. This finding contradicts the assertion by Vedeld (2007), that relatively wealthier households extract more forest resources whereas the poorer ones are more dependent on them.

In the context of this study, it is shown that the more dependent households are indeed also the heaviest extractors of forest resources. The less dependent group is also characterized by greater levels of livelihood diversification and land tenure security and lower levels of vulnerability. Other key differences have to do with the higher percentage of illiterate household heads as well as a lower percentage of household heads with education above the secondary level among the very dependent group. The ownership of productive farm tools is also significantly in favour of the less dependent group. 
Table 3: Household characteristics by level of forest dependence

\begin{tabular}{llll}
\hline & \multicolumn{3}{l}{ Mean or Proportion by level of forest dependence } \\
\hline Household size & Less dependent & Dependent & Very dependent \\
\hline Forest income** & 3.4 & 4.2 & 3.8 \\
\hline Household under 15 & 197.99 & 984.73 & 1732.44 \\
\hline Dependency ratio & 1.3 & 1.6 & 1.6 \\
\hline Active adults & 0.67 & 0.73 & 0.92 \\
\hline Sex= Male* & 2 & 2.6 & 2.1 \\
\hline Age & 0.62 & 0.74 & 0.67 \\
\hline years of residence & 38.8 & 45.1 & 43.8 \\
\hline FBO membership* & 22.3 & 30.4 & 30.9 \\
\hline No. of livestock & 0.08 & 0.07 & 0.05 \\
\hline Tools & 2 & 2.7 & 1.4 \\
\hline Aggregate farm size (acres) & 81 & 63.9 & 62.5 \\
\hline PC farm size (acres) & 3.7 & 5.1 & 3.9 \\
\hline Diversification index & 1.9 & 2.2 & 1.9 \\
\hline Tenure security* & 2.3 & 2 & 1.4 \\
\hline Vulnerability index & 0.9 & 0.67 & 0.73 \\
\hline Married* & 0.95 & 1.6 & 1.7 \\
\hline Illiterate* & 0.52 & 0.63 & 0.6 \\
\hline JSS/Middle School* & 0.14 & 0.17 & 0.32 \\
\hline Secondary* & 0.19 & 0.02 & 0.11 \\
\hline N & 0.12 & 0.01 & 0.02 \\
\hline & $86(0.033)$ & $89(0.034)$ & $85(0.033)$ \\
\hline & & & \\
\hline & & & \\
\hline
\end{tabular}

* Proportion, **Ghana Cedis, 1 USD to 3.2 Cedis, Source: Field work, 2014

\section{Determinants of Forest Dependence}

The difference between absolute forest income and relative forest income and their variations across different socioeconomic groups raises very important issues for analyzing the household-forest relationship. This is because although a household's extraction of forest resources (absolute forest income) may be relatively large, its economic reliance or dependence (relative forest income) may be rather low and vice versa. Thus, the factors affecting a household's level of dependence on forests was of particular interest in the subsequent analysis. A robust regression of household level characteristics, assets and other contextual factors on its relative forest income was ran to identify correlates of forest dependency within the study communities. The dependent variable in the forest dependency model is the share of forest income in household income (relative forest income) for the year under study. Explanatory variables are those that reflect household demographics, human resource assets, productive assets, and other conditioning factors. 
Table 5 presents the results as well as the explanatory variables used in the regression analysis. The factors identified as significant and positive in explaining (promoting) the rural household's dependence on forests are the household size, number of livestock owned, years of residence, household vulnerability index and farming as the most important income source for the household. On the other hand, significant factors that help to reduce the rural household's dependence on forests are its savings, farm size per capita, degree of income diversification, non-farm income and land tenure security.

Table 4: Regression results for the determinants of forest dependence

\begin{tabular}{|c|c|c|}
\hline Variable & Definition & $\begin{array}{l}\text { Coefficient } \\
\text { (Standard Error) }\end{array}$ \\
\hline Yrs_lived & no. of years household head has lived in the community & $0.192^{-2}\left(0.919^{-3}\right)^{* *}$ \\
\hline Tools & value of farm tools owned by household & $0.348^{-4}\left(0.586^{-4}\right)$ \\
\hline Vul_index & number of household shocks in the year & $0.019(0.009)^{* *}$ \\
\hline Savings & total household savings & $-0.386^{-4}\left(0.165^{-4}\right)^{* *}$ \\
\hline Household_size & number of household members & $0.229^{-4}\left(0.137^{-4}\right)^{*}$ \\
\hline PCFarmSize & household farm size per capita & $-0.013(0.005)^{* * *}$ \\
\hline Male (dummy) & household head is male & $0.041(0.031)$ \\
\hline Age & age of household head & $0.003(0.01)$ \\
\hline Age_squared & age of household head squared & $-0.391^{-4}\left(0.879^{-4}\right)$ \\
\hline $\begin{array}{l}\text { Ahumahumaso } \\
\text { (dummy) }\end{array}$ & study community is Ahumahumaso & $0.027(0.033)$ \\
\hline Liv_index & household livelihood diversification index & $-0.155(0.022)^{* * *}$ \\
\hline inc_nonfarm & household total non-farm income & $\begin{array}{l}-4.431 \\
\left(0.139^{-4}\right) * * *\end{array}$ \\
\hline fbo_memshp (dummy) & household head membership of FBO & $-0.079(0.055)$ \\
\hline Livestock & number of livestock owned by household & $0.017(0.005)^{* * *}$ \\
\hline Migrant (dummy) & household head is a migrant & $-0.024(0.058)$ \\
\hline Dependency_ratio & household dependency ratio & $0.018(0.015)$ \\
\hline impt_inc_farming & most important income source is farming & $0.530(0.051)^{* * *}$ \\
\hline Married (dummy) & household head is married & $-0.005(0.031)$ \\
\hline Farm_inc & household total farm income & $-0.006(0.007)$ \\
\hline $\begin{array}{l}\begin{array}{l}\text { Tenure_security } \\
\text { (dummy) }\end{array} \\
\end{array}$ & land tenure security & $-0.071(0.028)^{* *}$ \\
\hline _Cons & Constant & $-0.129(0.198)$ \\
\hline Prob>F & & 0.00 \\
\hline \multicolumn{3}{|l|}{$R^{2}=0.5803$} \\
\hline$N=260$ & & \\
\hline
\end{tabular}


Household size was found to be significant and positively associated with forest dependence in the study communities. As noted by a forest guard:

If we are to apply the laws strictly, we will always be arresting them. However, we know they can go there [forests] for firewood to cook ...The problem is some households are too large because they have many children. In such cases, they harvest a lot of firewood for personal use and with larger families and high level of poverty; they are always in the forest looking for animals to hunt and fruits to feed their families (Forest Guard, Ahumahumaso).

The quotation above supports the assertion that large households have more mouths to feed and the livelihood burden is especially more on households with more dependent members (Jha, 2009) than is the case with smaller households.

The ownership of livestock in a rural setting is dependent on the availability and use of cheap and abundant fodder sources due to high cost of feed input. Reliance on forest fodder sources as well as forest trees and bamboo for the construction of pens and fences or enclosures is, therefore, the norm rather than the exception in the study communities. This helps explain the significant and positive association between the numbers of livestock owned and forest dependence among households in the community.

The number of years of residence of the household in the study communities also showed a positive and significant relationship to forest dependence because the more established would be more knowledgeable about local resource endowments and have more established networks and access to these resources relative to newer households to the community. The number of idiosyncratic shocks suffered by the household within the survey year measured by its vulnerability index is also significant and positive in explaining forest reliance. Households with a more income shocks tend to resort to increased forest related activities for filling the gap left by the unexpected income shortfalls as well as relying on forest resources as safety nets for the period in question. Related to this foregoing issue is that of the significant and positive relationship between forest dependence and households with farming as their most important income source. The nexus between rural farming and the natural resource base helps to explain this finding, in that rural farming depends on the natural environment. Rural farming is a very rudimentary industry characterized by relative small land holdings, low yields and problems with pests and diseases, in addition to the relative lack of access to credit facilities. Households depending on farming as the most important source of income therefore regularly resort to forest extraction for regular subsistence and for gap filling and safety net purposes. The turn to forest extraction is even more pronounced in the instance of crop failure due to the lack of better alternative livelihood options. 
On the other hand, significant factors that help to reduce a household's dependence on forests are household savings, farm size per capita, degree of income diversification, non-farm income and land tenure security. Household savings was significantly and negatively associated with forest utilization as was also the case with per capita farm size. A household's access to savings means that in the event of an unexpected short fall in income from other sources, it can rely on its savings to 'ride out the storm' depending on the quantum of savings and nature of the shortfall, without having to resort to a high degree of forest resource extraction. Households with larger farm sizes per capita are able to put more land under cultivation and are likely to generate more farm income relative to those with smaller per capita farm sizes. Such households would have less of a need for forest extraction on a scale as would be required by those with less farm income. Thus, the potential for forest extraction is reduced when households have better access to farmland among other factors.

The findings indicate a significant and negative relationship between the households' level of income diversification in the study communities with its dependence on forest resources. This finding is has also been observed by Illukpitiya \& Yanagida (2008) that rural households that have a more diversified livelihood portfolio are better placed to cope with any unexpected shortfalls in their income relative to the less diversified ones. In order words, the more income sources available to a household, the lower the quantum of forest resources it extracts. This is understandable in the light of earlier arguments regarding the low return and arduous nature of forest extraction activities.

The availability of off-farm employment opportunities and income in the study communities and its contribution to total household income (wealth) was significant and negatively associated with forest extraction as a supplementary income-generating activity. The involvement of households in agro-processing activities like cassava and oil palm processing in Ahumahumaso and Odumase respectively besides the ubiquitous food vending and provision shops that were common in both communities, served to provide the respective households with a very important income source as indicated by the average non-farm income shares of 32 percent of total household income. Households obtaining substantial income from non-farm sources are better placed to withstand idiosyncratic shocks and thus, less inclined to turn to low return forest extraction activities.

The security of tenure of land holdings has important implications on farm investments particularly in the type of crops cultivated, soil improvements and other farm management practices. Land tenure security was significant and negatively associated with forest 
dependence. A traditional ruler explained that young household and migrant household heads tend to harvest more resources because they do not have land:

For the young men and migrants who are family heads, harvesting of forest resources is sometimes the main source of income because they don't have their own lands for large farms. These are people who farm on their parents' lands or other peoples' lands and they are usually assigned only small portions. So they are always in the forest to cut down trees for sale

This means that households without certain bundle of rights on their farmlands are more likely to be dependent on forests than those with secure tenure rights. This would for example compel a farm household to opt for the cultivation of household staples instead of the more profitable perennial crops such as cocoa.

\section{Conclusions}

The paper examined the impact of the exploitation of forest resources on the welfare of the rural household based on a household survey and in-depth interviews. The results indicate high rates of forest resource exploitation and that many rural households are dependent upon forest resources for their livelihoods. The findings also support the hypothesis that the household's extraction of forest resources and consequently its dependence on forests are a function of its access to other livelihood assets, its vulnerability context as well as other household characteristics. Poor households were also shown to be the heaviest users of forest resources in terms of absolute extraction rates in comparison to the less poor households. The study reveals that household livelihood and income diversification was common at the study sites and was not merely a feature of aggregation across specialist households. The contribution of forests in the diversification of rural livelihoods was particularly significant given its important role in poverty reduction (Vedeld et al., 2004). Besides, livelihood diversification also helps with coping with the unexpected shortfalls in household income from given sources - income shocks (Barrett et al, 2001).

An examination of the households' average income from forest extraction activities against the level of forest dependence revealed that households in the study communities that extract more forest resources also rely more on them for their income. This finding contradicts that of Vedeld (2007) who posited that richer households by virtue of their access to more productive resources are able to extract more forest resources relative to poorer households even though their forest income shares of total income (dependence) are lower. The implication here also is that the poor who would benefit most from harvesting forest products are often faced with a diminishing resource and a declining capacity to exploit it. 
Econometric analysis of the determinants of the household's economic dependence on forest reveals that household heterogeneities are important factors that drive their livelihood activities. Household characteristics such as years of residence of the household head in a given community, the household vulnerability index, household size, livestock ownership and having farming as the most important source of income proved positive and significant in promoting forest dependency. On the other hand, household savings, per capita farm size, livelihood diversification, the availability of non-farm income and land tenure security proved negative and significant in depressing forest dependency. The fact that these factors are statistically significant in the model indicates their fundamental role as household level factors in driving forest extraction and engendering dependence on these resources. The fact that some household level factors proved less significant for household economic dependence on forest resources also reflects the fact that dependence on forests is not merely a function of the raw extraction rates but rather its contribution to total household income.

Breaking out of the cycle of forest dependence for the poorer households into more rewarding livelihood activities such as non-farm household enterprises is constrained by their access to financial capital particularly due to a dearth of rural wage employment. However, the potential for intensifying crop production particularly for cash and horticultural crops in the study communities as a poverty reduction measure is a realistic option in spite of the basic and subsistence level at which the majority of the households operate. The promotion of other nonfarm alternative livelihood activities such as apiculture, fish farming, poultry keeping and raising small ruminants would serve to present more livelihood diversification options to rural households particularly due to diminishing per capita land holdings. This would also provide a good approach to rural development pathway out of poverty subject to the supply of rural financial services. We believe that approaches aimed at diversifying household livelihood sources and generating non-farm income from activities already enumerated would result in lower levels of forest dependency and consequently meet conservation and development goals. The findings indicate the need for the development of forest policies that harmonize both development and conservation objectives. It is obvious that policies based upon assumptions of homogeneity of rural forest communities as well as households cannot deliver equitable access to common property resources. Management institutions therefore need to take the factors that condition the household's extraction of forest resources as well as its economic dependence on forests into account to ensure that their livelihood needs are met. This throws up the need to factor the needs of the poor in the formulation of forest policies to ensure that they are not marginalized.

The political economy of forest use and rural livelihoods in Ghana is saddled with two principal issues. The first is that the extraction and use of forest resources are high. Secondly, there is a 
dependence on forests especially among the poorest groups as indicated by its relative economic contribution to household income. These two issues as highlighted may lead to the overexploitation of forest resources resulting in a reduction of the long-term supplies of directuse values as well as environmental services. The need to strike a balance between forest extraction by local communities and arresting deforestation and preserving natural habitats has become even more imperative for biodiversity rich tropical countries in particular. This is principally because pursuing conservation agendas by restricting access to forest resources may also deprive rural households of their livelihoods and relegate them to levels of further impoverishment.

Policy interventions for rural development must therefore include those that help to secure and enhance the natural resource base, participatory forest management and monitoring systems and securing people's access and rights to such resources. Other interventions should also look at widening the rural household's livelihood base by focusing on alternative rural livelihoods (non-farm income) as viable alternatives to reducing pressure on the forests especially among forest-dependent communities. Longer-term options for addressing forest dependency should focus on improving access to education in rural communities. A higher level of education makes forest extraction activities less attractive due to higher opportunity costs of time. More importantly, education could open a pathway to other employment opportunities and facilitate out-migration for better jobs that reduce the extraction of forest resources. The policy options described above should help slow the rate of forest degradation and decline in order to protect biodiversity as well as guarantee or enhance rural livelihoods both in the present and for the future.

\section{Acknowledgement}

This study received funding from the German Academic Exchange Service (DAAD). 


\section{References}

Acheampong, E., \& Marfo, E. (2011). The impact of tree tenure and access on chainsaw milling in Ghana. Ghana J. Forestry, 27, 68-86.

Adhikari, B., Di Falco, S., \& Lovett, J. C. (2004). Household characteristics and forest dependency: Evidence from common property forest management in Nepal. Ecological Economics, 48(2), 245-257.

Amanor, K. (1999). Global restructuring and land rights in Ghana: Forest food chains, timber, and rural livelihoods. Research Report No. 108, Nordiska Afrikainstitutet, Uppsala.

Appiah, M., Blay, D., Damnyag, L., Dwomoh, F. K., Pappinen, A., \& Luukkanen, O. (2009). Dependence on forest resources and tropical deforestation in Ghana. Environment, Development and Sustainability, 11(3), 471-487.

Arnold, M., \& Townson, J. (1998). Assessing the potential of forest product activities to contribute to rural incomes in Africa. Overseas Development Institute, London.

Asamoah, A. K., Pinard, A. M., Cobbinah, R. J., Damnyag, L., Nutakor, E., Nketiah, S. K., Kyere, B., \& Nyarko, C. (2007). Chainsaw milling and trade in West Africa. Socioeconomic impact of chainsaw milling and the lumber trade in Ghana. DFID, Renewable Natural Resource Research Strategy (RNRRS)(FRP) PMP. 05-08, Natural Resource International, UK

Babulo, B., Muys, B., Nega, F., Tollens, E., Nyssen, J., Deckers, J., \& Mathijs, E. (2009). The economic contribution of forest resource use to rural livelihoods in Tigray, Northern Ethiopia. Forest Policy and Economics, 11(2), 109-117.

Balint, P. J. (2006). Improving community-based conservation near protected areas: The importance of development variables. Environmental Management, 38(1), 137-148.

Barham, B. L., Coomes, O. T., \& Takasaki, Y. (1999). Rain forest livelihoods: Income generation, household wealth and forest use. Unasylva, 198. pp. 34-42.

Barrett, C. B., Clark, M. B., Clay, D. C., \& Reardon, T. (2005). Heterogeneous constraints, incentives and income diversification strategies in rural Africa. Quarterly Journal of International Agriculture, 44(1), 37-60.

Barrett, C. B., Reardon, T., \& Webb, P. (2001). Nonfarm income diversification and household livelihood strategies in rural Africa: Concepts, dynamics, and policy implications. Food Policy, 26(4), 315-331.

Bebbington, A. (1999). Capitals and capabilities: A framework for analyzing peasant viability, rural livelihoods and poverty. World Development, 27(12), 2021-2044.

Brobbey, L. K., Hansen, C. P., Kyereh, B., \& Pouliot, M. (2019). The economic importance of charcoal to rural livelihoods: Evidence from a key charcoal-producing area in Ghana. Forest Policy and Economics, 101, 19-31.

Brown, D. R., Stephens, E. C., Ouma, J. O., Murithi, F. M., \& Barrett, C. B. (2006). Livelihood strategies in the rural Kenyan highlands. Afr. J. Agric. Res., 1 (2006), pp. 21-35. doi: 10.22004/ag.econ.57019

Byron, N., \& Arnold, M. (1999). What futures for the people of the tropical forests? World Development, 27(5), 789-805.

Cavendish, W. (1999). Poverty, inequality and environmental resources: Quantitative analysis of rural households. Working Paper Series 99-9, Centre for the Study of African Economies, Oxford.

Cavendish, W. (2000). Empirical regularities in the poverty-environment relationship of rural households: Evidence from Zimbabwe. World Development, 28(11), 1979-2003. 
Cavendish, W. (2002). Quantitative methods for estimating the economic value of resource use to rural households. Uncovering the Hidden Harvest: Valuation Methods for Woodland and Forest Resources, 17-65.

Chambers, R., \& Conway, G. (1992). Sustainable rural livelihoods: Practical concepts for the 21 st century. IDS Discussion Paper 296, Institute of Development Studies, Brighton.

Chilongo, T. (2014). Livelihood strategies and forest reliance in Malawi. Forests, Trees and Livelihoods, 23(3), 188-210.

Coomes, O. T., Barham, B. L., \& Takasaki, Y. (2004). Targeting conservation-development initiatives in tropical forests: Insights from analyses of rain forest use and economic reliance among Amazonian peasants. Ecological Economics, 51(1), 47-64.

Córdova, J. P. P., Wunder, S., Smith-Hall, C., \& Börner, J. (2013). Rural income and forest reliance in highland Guatemala. Environmental Management, 51(5), 1034-1043.

Dash, M., \& Behera, B. (2016). Determinants of household collection of non-timber forest products (NTFPs) and alternative livelihood activities in Similipal Tiger Reserve, India. Forest Policy and Economics, 73, 215-228.

Dercon, S. (1998). Wealth, risk and activity choice: Cattle in Western Tanzania. Journal of Development Economics, 55(1), 1-42.

DFID. (1999). Sustainable Livelihoods Guidance Sheets. DFID, London.

Domson, O., \& Vlosky, R. P. (2007). A strategic overview of the forest sector in Ghana, Working paper \#81. Forest Products Development Center, Louisiana

Ellis, F., \& Freeman, H. A. (2004). Rural livelihoods and poverty reduction strategies in four African countries. Journal of Development Studies, 40(4), 1-30.

Falconer, J. (1992). Non-timber forest products in southern Ghana. A summary report. ODA Forestry Series. No. 2, 23 Pp.

FAO. (2015). Global Forest Resources Assessment 2015: How are the World's Forests Changing?. Food and Agriculture Organization of the United Nations.

Fisher, M. (2004). Household welfare and forest dependence in Southern Malawi. Environment and Development Economics, 9(2), 135-154.

Gatiso, T. T., \& Wossen, T. (2015). Forest dependence and income inequality in rural Ethiopia: Evidence from Chilimo-Gaji community forest users. International Journal of Sustainable Development \& World Ecology, 22(1), 14-24.

Godoy, R., Overman, H., Demmer, J., Apaza, L., Byron, E., Huanca, T., Leonard, W., Perez, E., Reyes-Garcia, V., \& Vadez, V. (2002). Local financial benefits of rain forests: Comparative evidence from Amerindian societies in Bolivia and Honduras. Ecological Economics, 40(3), 397-409.

Illukpitiya, P., \& Yanagida, J. F. (2008). Role of income diversification in protecting natural forests: Evidence from rural households in forest margins of Sri Lanka. Agroforestry Systems, 74(1), 51-62.

Illukpitiya, P., \& Yanagida, J. F. (2010). Farming vs forests: Trade-off between agriculture and the extraction of non-timber forest products. Ecological Economics, 69(10), 19521963.

Jansen, H. G., Pender, J., Damon, A., Wielemaker, W., \& Schipper, R. (2006). Policies for sustainable development in the hillside areas of Honduras: A quantitative livelihoods approach. Agricultural Economics, 34(2), 141-153.

Jha, S. (2009). Household-specific variables and forest dependency in an Indian hotspot of biodiversity: Challenges for sustainable livelihoods. Environment, Development and Sustainability, 11(6), 1215-1223.

Lilieholm, R. J., \& Romney, L. R. (2000). Tourism, national parks and wildlife. Tourism and National Parks: Issues and Implications, 137. 
Mamo, G., Sjaastad, E., \& Vedeld, P. (2007). Economic dependence on forest resources: A case from Dendi District, Ethiopia. Forest Policy and Economics, 9(8), 916-927.

McSweeney, K. (2004). Forest product sale as natural insurance: The effects of household characteristics and the nature of shock in eastern Honduras. Society and Natural Resources, 17(1), 39-56.

Neumann, R. P., \& Hirsch, E. (2000). Commercialisation of non-timber forest products: Review and analysis of research: Review and analysis of research. Center for International Forestry Research, FAO. Rome.

O'Gorman, T. L. (2006). Species and People: Linked futures. WWF International, Gland, Switzerland.

Reardon, T., \& Vosti, S. A. (1995). Links between rural poverty and the environment in developing countries: Asset categories and investment poverty. World Development, 23(9), 1495-1506.

Scoones, I. (1998). Sustainable rural livelihoods: A framework for analysis, Working Paper 72, Institute for Development Studies, Brighton.

Takasaki, Y., Barham, B. L., \& Coomes, O. T. (2000). Rapid rural appraisal in humid tropical forests: An asset possession-based approach and validation methods for wealth assessment among forest peasant households. World Development, 28(11), 1961-1977.

Tittensor, D. P., Walpole, M., Hill, S. L., Boyce, D. G., Britten, G. L., Burgess, N. D., Butchart, S. H., Leadley, P. W., Regan, E. C., \& Alkemade, R. (2014). A mid-term analysis of progress toward international biodiversity targets. Science, 346(6206), 241-244.

Vedeld, P., Angelsen, A., Sjaastad, E., \& Berg, G. K. (2004). Counting on the Environment: Forest Incomes and the Rural Poor. Environmental Economics Series Paper No. 98, World Bank, Washington DC.

Vedeld, Paul, Angelsen, A., Bojö, J., Sjaastad, E., \& Kobugabe Berg, G. (2007). Forest environmental incomes and the rural poor. Forest Policy and Economics, 9(7), 869879.

Whitesell, S., Lilieholm, R. J., \& Sharik, T. L. (2002). A global survey of tropical biological field stations. BioScience, 52(1), 55-64.

Wiggins, S., Marfo, K., \& Achirinah, V. (2004). Protecting the Fores or the People? Environmental Policies and Livelihoods in the Forest Margins of Southern Ghana. World Development, 32(11), 1939-1955. https://doi.org/doi:10.1016/j.worlddev.2004.05.008

Wunder, S. (2005). Poverty alleviation and tropical forests: What scope for synergies? The Earthscan Reader in Forestry and Development. Earthscan, UK, p107-129.

Wunder, S., Angelsen, A., \& Belcher, B. (2014). Forests, livelihoods, and conservation: Broadening the empirical base. Elsevier. 